\title{
Evaluation of the immunomodulatory activity of thalidomide on tumor-associated macrophages in the 4T1 murine metastatic breast cancer model
}

[Avaliação do efeito imunomodulador da talidomida em macrófagos associados a tumores no modelo murino de câncer de mama metastático 4T1]

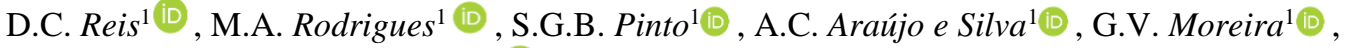

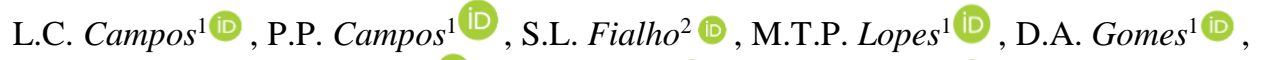 \\ R.C. Russo ${ }^{1}$ (D) E. Ferreira ${ }^{1 *}$ (D) G.D. Cassali ${ }^{1 * \#(D)}$
}

${ }^{1}$ Universidade Federal de Minas Gerais, Instituto de Ciências Biológicas, Belo Horizonte, MG, Brasil ${ }^{2}$ Fundação Ezequiel Dias, Belo Horizonte, MG, Brasil

\begin{abstract}
The present work evaluated the immunomodulatory effect of thalidomide (Thal) at different doses on tumorassociated macrophages (TAMs) using a mouse model of human breast cancer. Mice were inoculated with 4T1 cells in the left flank and treated with Thal once a day at concentrations of 50,100 , and $150 \mathrm{mg} / \mathrm{kg}$ body weight from the 5th day until the 28th day of tumor inoculation. The tumors were sized, proliferation index and TAMs count were evaluated in primary tumors and metastatic lungs. In addition, the metastasis rate was evaluated in the lungs. Thal at $150 \mathrm{mg} / \mathrm{kg}$ significantly decreased tumor growth, proliferation index, and TAMs infiltration in primary tumors. Conversely, a higher number of TAMs and lower proliferation index were observed in metastatic lungs in mice treated with $150 \mathrm{mg} / \mathrm{kg}$ of Thal. Furthermore, Thal at $150 \mathrm{mg} / \mathrm{kg}$ significantly decreased the metastatic nodules in the lungs. Our findings demonstrated that Thal treatment considerably decreased the primary tumor and lung metastasis in mice associated with different TAM infiltration effects in these sites.
\end{abstract}

Keywords: breast cancer, immunomodulation, thalidomide, inflammation, tumor-associated macrophages

\section{RESUMO}

No presente trabalho, foi avaliado o efeito imunomodulador de diferentes doses de talidomida em macrófagos associados ao tumor (TAMs), em um modelo murino de câncer de mama. Camundongos foram inoculados com células 4T1, na região do flanco esquerdo, e tratados com talidomida, uma vez ao dia, nas doses de 50, 100 e $150 \mathrm{mg} / \mathrm{k}$, por massa corporal, do quinto dia ao $28^{\circ}$ dia de inoculação tumoral. Os tumores foram medidos, o índice de proliferação celular e a contagem de TAMs foram avaliados nos tumores primários e nos pulmões com metástases. Além disso, a taxa de metástases pulmonares também foi avaliada. A talidomida na dose de $150 \mathrm{mg} / \mathrm{kg}$ diminuiu significativamente o crescimento tumoral, o índice de proliferação celular e a infiltração de TAMs nos tumores primários. Por outro lado, maior número de TAMs e menor índice de proliferação celular foram observados nos pulmões metastáticos, em camundongos tratados com 150mg/kg de talidomida. Ademais, a talidomida na dose de $150 \mathrm{mg} / \mathrm{kg}$ diminuiu significativamente os nódulos metastáticos nos pulmões. Os resultados demonstraram que o tratamento com talidomida diminuiu o crescimento tumoral e as metástases pulmonares em camundongos, associado com diferentes efeitos na infiltração de TAMs nesses locais.

Palavras-chave: câncer de mama, imunomodulação, talidomida, inflamação, macrófagos associados ao tumor

\section{INTRODUCTION}

The tumor microenvironment comprises different cell types, including stromal and inflammatory cells (Quail and Joyce, 2013). Solid tumors are commonly infiltrated with innate immune cells, including tumor-associated macrophages (TAMs), which represent the major inflammatory component of many tumors' stroma (Ruffell et al., 2012; Mei et al., 2016). TAMs may either block

*Corresponding author: cassalig@icb.ufmg.br

Submitted: March 2, 2021. Accepted: August.2021.

\#These authors contributed equally for this work 
or facilitate tumor growth, depending on their activation status. M1-polarized TAMs are recognized as anti-tumoral macrophages, whereas M2-polarized TAMs are shown to have protumoral activities (Laoui et al., 2011; Murray et al., 2014). In human breast carcinomas, M2-like TAMs density correlates with poor prognosis (Pollard, 2008; Lindsten et al., 2017), and macrophage depletion has been shown to delay tumor progression (Laoui et al., 2011).

In recent years, Thal has exhibited immunomodulatory and anti-angiogenic properties in inflammatory and neoplastic diseases (Eleutherakis-Papaiakovou et al., 2004). The immunomodulatory mechanism had been linked to the protein Cereblon, which in turn is the primary target of Thal teratogenicity (Ito et al., 2010). In multiple myeloma, this protein is required for response to immunomodulatory drugs, and its decreased expression has been correlated with resistance to therapy (Zhu et al., 2011). In contrast, cereblon-deficient mice presented the Thal's immunomodulatory effect, even in the absence of cereblon (Millrine et al., 2016).

Herein, we used the murine mammary carcinoma 4T1 to evaluate the effect of different doses of Thal in TAMs infiltration and metastatic tumor growth. The 4T1 tumor is a highly metastatic cell line that transplanted to the mammary gland can spontaneously metastasize from the primary tumor to multiple distant sites, including lymph nodes, liver, lung, brain, and bone (Pulaski and Ostrand-Rosenberg, 2001). Interestingly, previous studies have shown that an increased myeloid cell infiltration follows 4T1 tumor development into the primary tumor and its metastasis (DuPré et al., 2007; Reis et al., 2019), making it a useful model to study the role of TAMs in breast carcinogenesis.

\section{METHODS}

The 4T1 mouse mammary tumor cell line was obtained from the American Type Culture Collection (Manassas, USA). 4T1 cells were maintained in RPMI 1640 medium (Hyclone, Logan, UT) containing $10 \%$ fetal bovine serum (FBS) (Hyclone, Logan, UT), $100 \mathrm{U} / \mathrm{ml}$ of penicillin and $100 \mu \mathrm{g} / \mathrm{ml}$ of streptomycin (Invitrogen) at $37^{\circ} \mathrm{C}$ in a humidified atmosphere of $5 \% \mathrm{CO}_{2}$.
Thirty-two six-week-old female BALB/c mice were acquired from the Animal Facility-Institute of Biological Science-Federal University of Minas Gerais; Belo Horizonte-Brazil. Mice were divided into four groups $(n=8)$ and kept in polycarbonate cages and had free access to mouse chow (Quimtia, Paraná, Brazil) and water ad libitum. Mice were housed under standard laboratory conditions at $25^{\circ} \mathrm{C}$ in a 12 -hr light: dark cycle. All procedures were performed under the guidelines and with the approval of the Ethics Committee in Animal Experimentation of the Federal University of Minas Gerais (CEUA:262/2012).

Mice were subcutaneously inoculated with $2.5 \times 10^{6} 4 \mathrm{~T} 1$ cells in the left flank area. Treatment started five days of tumor inoculation and continued for 23 days. Thal (kindly provided by Fundação Ezequiel Dias, Belo Horizonte, Brazil) was diluted in saline $0.9 \%$ and $0.25 \%$ Tween (Dako, Carpinteria, USA) at final concentrations of 50,100 , and $150 \mathrm{mg} / \mathrm{kg} / \mathrm{bodyweight} \mathrm{day} \mathrm{and} \mathrm{it}$ was daily administered by gavage. The control group received vehicle (saline $0.9 \%+$ Tween 20 $0.25 \%$ ) using the same regimen. Tumor-bearing mice were weighed, and the primary tumor was measured with a caliper every other day. Tumor volume was calculated using the formula: tumor volume $\left(\mathrm{mm}^{3}\right)=($ length $\mathrm{x}$ width) $2 / 2$ (Wang et al. 2020). On day 29, after tumor inoculation, mice were euthanized by anesthetic overdose (sodium pentobarbital $50 \mathrm{mg} / \mathrm{kg}$, intraperitoneal injection (i.p). Blood was collected for biochemical evaluation of urea, creatinine, aspartate aminotransferase (AST), alanine aminotransferase (ALT), and gamma-glutamyl transferase (GGT) and complete blood count (CBC). Primary tumor and lung were collected, weighed, and sampled for histopathological, biochemical, and cytokine analysis. Blood smears were prepared and stained with May-GrunwaldGiemsa (Sigma-Aldrich) for differential leukocyte evaluation through an optical microscope Olympus BX50 (Japan), 40x objective.

Primary tumor and right lung samples from 4T1 tumor-bearing mice were weighed and homogenized to perform the ELISA, as previously described (Reis et al., 2019). The cytokine TNF- $\alpha$ and chemokine CCL2 were quantified using DuoSet ELISA kit (R\&D Systems, Minneapolis, MN, USA). For 
histopathological, histomorphometry, and lung metastasis evaluation, primary tumor and left lung fragments were fixed in $10 \%$ buffered formalin for $48 \mathrm{~h}$, embedded in paraffin, and processed for light microscopic evaluation of hematoxylin and eosin (H\&E) stained slides. For metastasis assessment, neoplastic cellular nodules disseminated throughout the lung parenchyma or alveolar spaces were considered metastatic lesions (Reis et al., 2019). Metastasis quantification was performed by counting the total of metastatic nodules in one section from the left lung (single lobe) in an Olympus microscope (BX-40), using the 10x and 40x objectives. The inflammatory infiltrates in the primary tumor were systematically classified based on the distribution (as focal: the presence of 1-3 inflammatory foci; multifocal: the presence of more than three inflammatory foci; and diffuse: the presence of inflammatory cells evenly distributed in the tumor section) and intensity (discrete + , moderate ++ or intense +++ ), as described by Estrela-Lima et al., (2010). Cell profiles were classified into mononuclear, polymorphonuclear, and mixed inflammatory cell patterns. For histomorphometry analysis, the percentages of the tumor, necrosis, inflammation (inflammatory cells, hemorrhage, and edema), and normal tissue areas were calculated in 15 histologic fields using a graticule scale of 25 dots. Histological images were obtained from the capture system using a SPOT 3.4.5 $\mathrm{Basic}^{\circledR}$ camera adapted to an Olympus microscope (BX-40) and the images were analyzed using Corel Draw ${ }^{\circledR}$ software version 7.468 .

Immunohistochemistry assay was performed on formalin-fixed, paraffin-embedded (FFPE) tissue $(4 \mu \mathrm{m})$ of primary tumors and lungs deparaffinized in xylene and rehydrated in graded alcohol. Antigen retrieval was achieved by water bath boiling for 20 minutes in citrate buffer $\mathrm{pH} 6$ (DakoCytomation, Carpinteria, CA, USA) at $98^{\circ} \mathrm{C}$. Endogenous peroxidase activity was blocked with $3 \%$ hydrogen peroxidase in methanol. For blocking of non-specific binding Biotin blocking system (Dako) was used. Primaries antibodies (CDC47, 1:300, clone 47DC141, Neomarkers, Fremont, CA or iNOS2, 1:300, polyclonal, Santa Cruz Biotechnology, Europe) were incubated for one hour and secondary anti-rabbit HRP antibody (Advance HRP enzyme, Dako) for $30 \mathrm{~min}$ at room temperature. Slides were stained with diaminobenzidine (DAB) chromogen (Dako) and counterstained with hematoxylin. CDC47 expression index was obtained by estimating the percentage of positive cells in 500 tumor cells (Souza et al., 2012). iNOS2 expression was analyzed using the ImageJ software (https://imagej.nih.gov/ij/). Ten images at 40x magnification were obtained from the capture system with a SPOT 3.4.5 Basic $^{\circledR}$ micro-camera adapted to an Olympus light microscope (BX-40).

Immunofluorescence and confocal microscopy were also performed in the primary tumor and lung FFPE fragments, as previously described, with minor changes (Reis et al., 2019). Primaries antibodies used were F4/80 (1:150, clone mAb BM8, Hycult Biotech, Uden, The Netherlands) and conjugated anti-CD11b-PE (1:100, clone $\mathrm{M} 1 / 70$, BD Biosciences, USA) to label macrophages (Zaynagetdinov et al., 2013; Wang et al., 2020). The secondary antibody used was Goat Anti-Rabbit IgG Alexa Fluor $^{\circledR} 488$ (1:1000, Life Technologies). Nuclei were stained with Hoechst dye $33258 \quad(1 \mu \mathrm{g} / \mathrm{mL}$, Life Technologies) before coverslip mounting for immunofluorescence and confocal laser scanning microscopy (Zeiss LSM 5 Live, Carl Zeiss, Jena, Germany) using an oil 40x 1.3 NA objective lens. Immunoreaction was considered positive for macrophages when cell staining was observed on mononuclear cells for the F4/80 marker alone or F4/80 and CD11b markers (double-positive cells), but not to cells that only expressed CD11b marker. Since the anti-F4/80 antibody also stains eosinophils (McGarry; Stewart, 1991; DuPré et al., 2007; Zaynagetdinov et al., 2013), any staining on segmented nucleus' cells were not considered as macrophages. The F4/80 protein is also expressed at a lower level on monocytes and a small population of spleen dendritic cells (Zaynagetdinov et al., 2013); thus, we do not discard some of these cells that may be present in the primary tumors and lungs.

Statistical analyses were performed using the Graph Pad Prism v.5 software (San Diego, CA). The Kruskal Wallis test followed by Dunn's posthoc test was used to assess whether there were differences in tissue inflammation among control and Thal treated groups. The one-way ANOVA test followed by the Student-Newman-Keuls posthoc test was used to assess differences in parametric data. The values were considered significant when $\mathrm{P}<0.05$. 


\section{RESULTS}

Thal's oral administration $(50,100,150 \mathrm{mg} / \mathrm{kg})$ on 4T1 tumor-bearing mice did not present side effects in biochemical serum indices for urea, creatinine, AST and GGT as compared to the control group (Table 1). High ALT levels were observed in the group treated with $100 \mathrm{mg} / \mathrm{kg}$ of Thal as compared to the control group $(P<0.01)$ (Table 1). For hematological indices, a decrease in total leukocytes was observed in the groups treated with $100 \mathrm{mg} / \mathrm{kg}$ and $150 \mathrm{mg} / \mathrm{kg}$ of Thal $(P<0.05)$ as compared to the control group (Table $2)$. Thal at a dose of $150 \mathrm{mg} / \mathrm{kg}$ significantly inhibited tumor growth as compared to the control group $(P<0.05)$ (Fig. 1A). Histological analyses revealed a diffuse inflammatory infiltrate distributed predominately in peripheral areas of primary tumors. It was greater in the groups treated with $100 \mathrm{mg} / \mathrm{kg}$ and $150 \mathrm{mg} / \mathrm{kg}$ of Thal $(P<0.05) \quad$ (Fig. 1B-C). The intratumoral inflammatory infiltrates in most tumors were weak, consisting of mononuclear cells and often associated with necrosis areas, except from tumors treated with $150 \mathrm{mg} / \mathrm{kg}$ of Thal, which showed greater infiltration of mononuclear cells $(P<0.01) \quad$ (Fig. 1B). The histomorphometry analysis corroborated these results, showing high inflammation areas in tumors treated with $100 \mathrm{mg} / \mathrm{kg}(P<0.01)$ and $150 \mathrm{mg} / \mathrm{kg}(P<0.001)$ of Thal (Fig. 1D). Additionally, a decrease in necrotic area percentage were found in tumors treated with $150 \mathrm{mg} / \mathrm{kg}$ of Thal $(P<0.05)$ (Fig. 1D). Furthermore, Thal treatment reduced neoplastic areas with significant differences in the groups treated with 50 and $100 \mathrm{mg} / \mathrm{kg}$ compared with the control group $(P<0.05)$ (Fig. 1D).

Table 1. Thalidomide effects in the serum of control and Thal treated groups

\begin{tabular}{lcccc} 
& Control & Thal 50 & Thal 100 & Thal 150 \\
\hline Urea $(\mathrm{mg} / \mathrm{dl})$ & $74.6 \pm 46.3$ & $106.5 \pm 54.6$ & $82.7 \pm 39.9$ & $91,9 \pm 25.6$ \\
Creatinine $(\mathrm{mg} / \mathrm{dL})$ & $1.9 \pm 1.2$ & $2.7 \pm 0.6$ & $2.4 \pm 0.6$ & $2.7 \pm 0.6$ \\
AST (U/L) & $199.1 \pm 64.54$ & $241.5 \pm 40.04$ & $250.6 \pm 28.48$ & $254.1 \pm 45.11$ \\
ALT (U/L) & $56.3 \pm 13.6$ & $77.0 \pm 12.02$ & $98.7 \pm 32.85^{* *}$ & $84.1 \pm 24.03$ \\
GGT (U/L) & $1.3 \pm 0.5$ & $1.7 \pm 0.5$ & $1.9 \pm 0.07$ & $2.0 \pm 0.8$ \\
\hline
\end{tabular}

AST: Aspartate Aminotransferase, ALT: Alanine Aminotransferase, GGT: Gamma-glutamyltransferase. The results relate to the average \pm standard deviation. $* * P<0.01$.

Table 2. Thalidomide effects in the hematological index of control and Thal treated groups

\begin{tabular}{lccccc}
\hline & Control & Thal 50 & Thal 100 & Thal 150 \\
\hline Erythrocytes $\left(/ \mathrm{mm}^{3}\right)$ & $8.14 \pm 1.623$ & $7.77 \pm 2.30$ & $8.654 \pm 0.46$ & $9.353 \pm 0.47$ \\
Hemoglobin $(\mathrm{g} / \mathrm{dl})$ & $13.24 \pm 2.56$ & $12.76 \pm 3.43$ & $13.96 \pm 0.81$ & $14.89 \pm 1.21$ \\
Hematocrit $(\%)$ & $42.89 \pm 12.03$ & $40.04 \pm 13.62$ & $47.56 \pm 4.85$ & $50.59 \pm 3.83$ \\
MCV (fl) & $49.60 \pm 6.40$. & $49.16 \pm 5.35$ & $54.23 \pm 4.10$ & $53.11 \pm 2.94$ \\
& & & & \\
White Blood Cells $\left(/ \mathrm{mm}^{3}\right)$ & $8.374 \pm 1.24$ & $7.781 \pm 1.20$ & $6.741 \pm 0.84 *$ & $6.574 \pm 0.81^{*}$ \\
Lymphocytes $(\%)$ & $6.9 \pm 3.5$ & $8.6 \pm 4.6$ & $10.3 \pm 2.9$ & $11.4 \pm 5.8$ \\
Neutrophil granulocytes $(\%)$ & $85.9 \pm 1.5$ & $84.6 \pm 3.9$ & $81.4 \pm 5.6$ & $81.1 \pm 6.9$ \\
Monocytes $(\%)$ & $1.6 \pm 0.5$ & $1.6 \pm 1.1$ & $2.3 \pm 1.2$ & $2.3 \pm 1.0$ \\
Band neutrophil (\%) & $1.9 \pm 1.3$ & $2, .6 \pm 0.9$ & $3.1 \pm 1.9$ & $2.6 \pm 1.3$ \\
Eosinophil granulocytes $(\%)$ & $0.0 \pm 0.0$ & $0.0 \pm 0.0$ & $0.0 \pm 0.0$ & $0.0 \pm 0.0$ \\
Basophil granulocytes $(\%)$ & $0.0 \pm 0.0$ & $0.0 \pm 0.0$ & $0.0 \pm 0.0$ & $0.0 \pm 0.0$ \\
Ring cell (\%) & $2.7 \pm 1.4$ & $2.6 \pm 1.7$ & $2.3 \pm 2.3$ & $2.6 \pm 1.3$ \\
Blasts $(\%)$ & $0.3 \pm 0.7$ & $0.0 \pm 0.0$ & $0.4 \pm 1.1$ & $0.0 \pm 0.0$
\end{tabular}

Platelets $\left(/ \mathrm{mm}^{3}\right)$ 
A

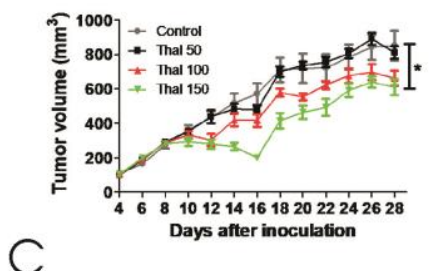

B

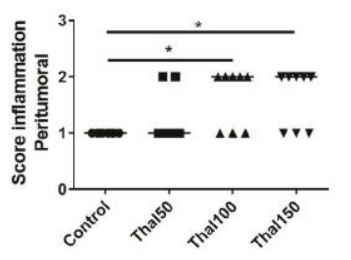

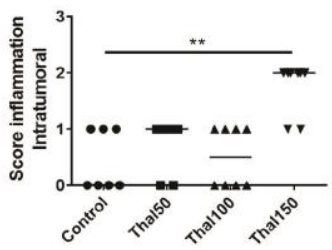
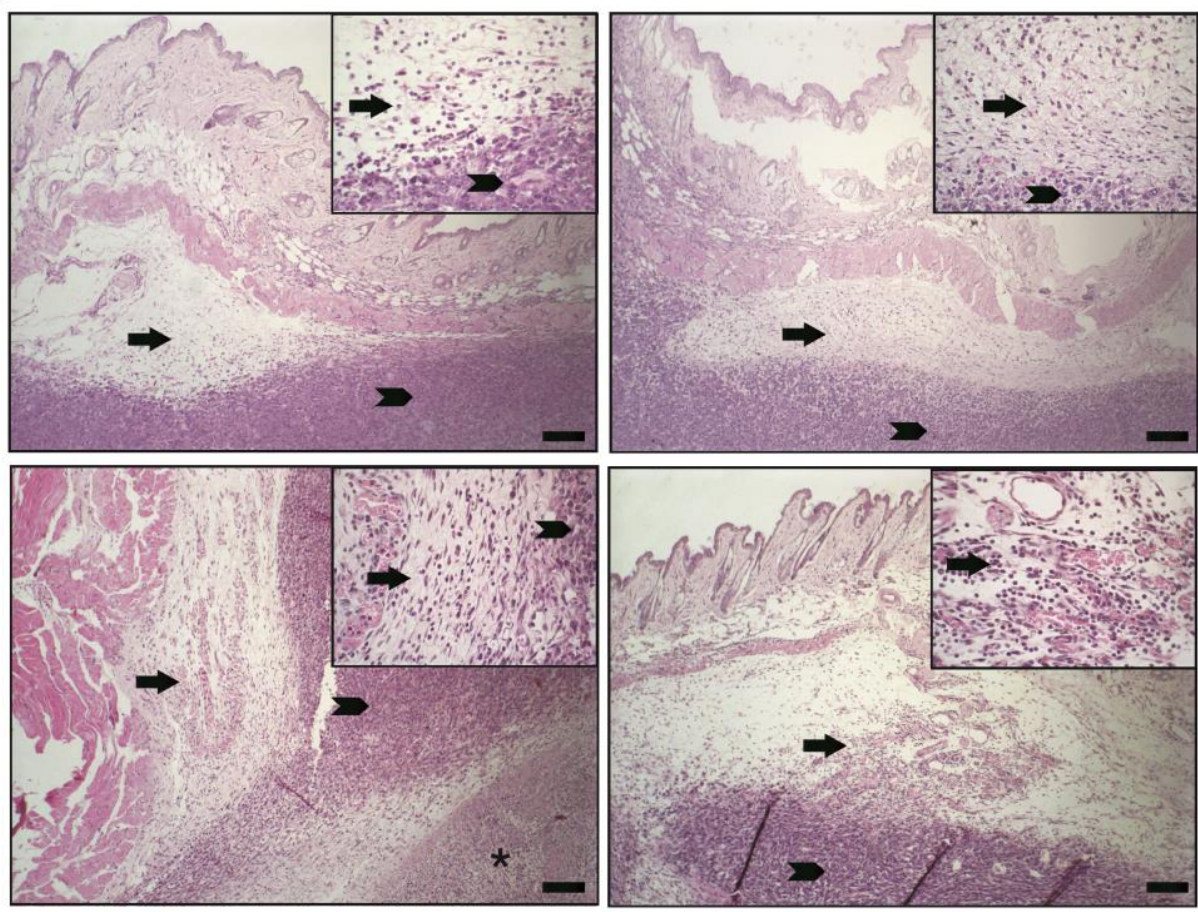

D

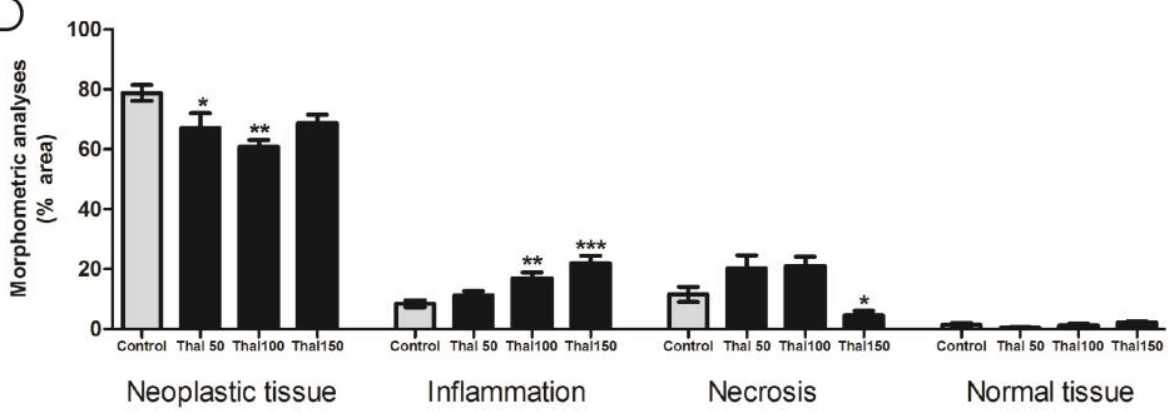

Figure 1. Thalidomide decreased 4T1 tumor growth associated with increased tumor inflammatory infiltration. (A) Growth curve. (B) Inflammation evaluation on the primary tumor. (C) Representative H\&E images of peripheral and tumor areas. Inflammation and edema are shown in peripheral areas (arrow). Arrowhead and asterisks indicate tumor and necrotic areas, respectively. (D) Morphometric analysis. Results are shown as the mean \pm SEM in (A) and (C) or median in (B). One-way ANOVA test followed by the Student-Newman-Keuls post-hoc test was used to evaluate differences in (A) and (D). Kruskal-Wallis test followed by Dunn's test was used to evaluate differences in (C). $* P<0.05, * * P<0.01, * * * P<0.001$, respectively.

To confirm Thal's anti-tumor effect in the primary tumor and lung metastasis on 4T1 tumor-bearing mice, we assessed the proliferation index of tumor cells by CDC47 expression. Mice treated with
$100 \mathrm{mg} / \mathrm{kg}$ and $150 \mathrm{mg} / \mathrm{kg}$ of Thal presented a lower neoplastic proliferation index in primary tumors than mice from the control group $(P<0.05)$ (Fig. 2A-B). In the lung, Thal treatment reduced 
proliferation index of metastatic nodules at dose of $50 \mathrm{mg} / \mathrm{kg}(P<0.05), 100 \mathrm{mg} / \mathrm{kg}(P<0.05)$ and $150 \mathrm{mg} / \mathrm{kg}(P<0.01)$ (Fig. 2C-D). Besides, the histological analysis also revealed a reduction in
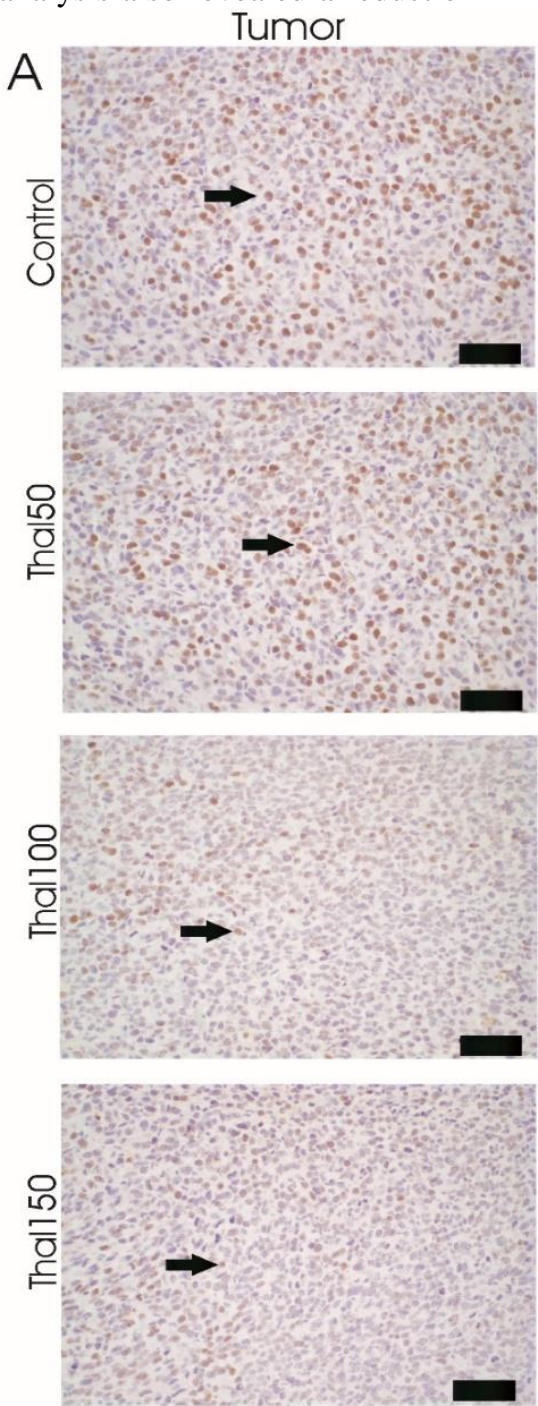

B

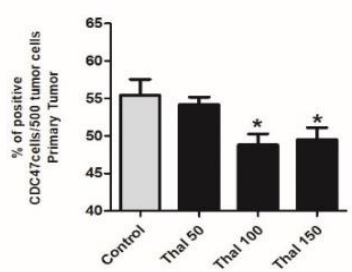

the number of metastatic lung nodules from the $150 \mathrm{mg} / \mathrm{kg}$ Thal-treated group as compared to the control $(P<0.05)$ (Figure 2E).
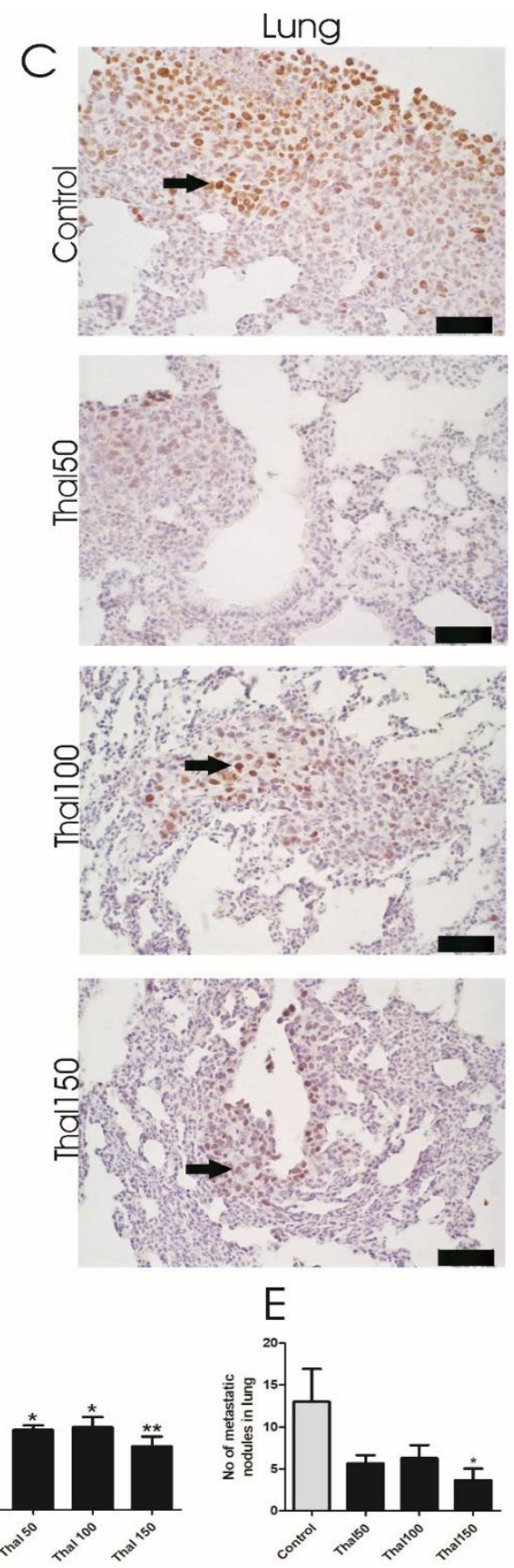

Figure 2. Thalidomide reduces the neoplastic proliferation of primary tumor and lung metastases of the 4T1 tumor. (A) Representative images of tumor cross-sections stained with 3,3'-diaminobenzidine (DAB) by immunohistochemistry. (B) Proliferative index quantification. (C) Representative images of lung metastases cross-sections stained with DAB by immunohistochemistry. (D) Proliferative index quantification. (E) Metastasis quantification. Arrows show CDC47+ positive cells in primary tumor and lung metastasis. Results are shown as the mean \pm SEM. One-way ANOVA test followed by the Student-Newman-Keuls post-hoc test to evaluate differences in B, D, and E. $* P<0.05$, $* * P<0.01$. 
Next, we measured the levels of CCL2 and TNF- $\alpha$ in the primary tumor and lungs of 4T1 tumor-bearing mice. We observed a reduction of CCL2 levels only in mice treated with $50 \mathrm{mg} / \mathrm{kg}$ of Thal $(P<0.05)$ (Figure 3A), while no significant changes were observed in TNF- $\alpha$ levels (Figure 3B). In the lung, higher CCL2 levels were found after $150 \mathrm{mg} / \mathrm{kg}$ of Thal as compared to control $(P<0.001)$, Thal $50 \mathrm{mg} / \mathrm{kg}(P<0.01)$, and Thal $100 \mathrm{mg} / \mathrm{kg}(P<0.05)$ groups (Figure 4A). Higher TNF- $\alpha$ levels were found after $100 \mathrm{mg} / \mathrm{kg} \quad(P<0.05)$ and $150 \mathrm{mg} / \mathrm{kg}$ $(P<0.01)$ of Thal as compared to control group and $50 \mathrm{mg} / \mathrm{kg}$ Thal-treated group $(P<0.05)$ (Figure 4B). To assess the immunomodulatory effect of Thal on TAMs, confocal analyses were carried out. On primary tumors, most infiltrating macrophages were double-positive cells to the F4/80+ and CD11b+ markers, and they were predominantly found in peripheral tumor areas. Thal treatment reduced these cells at dose of $50 \mathrm{mg} / \mathrm{kg} \quad(P<0.05), 100 \mathrm{mg} / \mathrm{kg}$ $(P<0.01)$ and $150 \mathrm{mg} / \mathrm{kg}(P<0.01)$ as compared to the control group. In the lungs, two macrophage populations were identified based on the cell-surface expression of the F4/80 marker combined with CD11b marker: F4/80+CD11b- cells and F4/80+CD11b+ cells. (Figure 3C-D). The F4/80+CD11b- macrophages increased progressively after 50,100 , and $150 \mathrm{mg} / \mathrm{kg}$ of Thal administration $\quad(P<0.05, \quad P<0.01, \quad P<0.001$, respectively), while no differences were found among the groups to the F4/80+CD11b+ macrophages (Figure 4C-D). Furthermore, differences in the distribution and macrophages morphology were visualized in control and treated groups. In Thal groups, TAMs were found distributed as multifocal aggregates, while in the control group, these cells showed isolated and diffusely distributed in the lung parenchyma (Fig. 4D). Yet, macrophages from the Thal-treated group showed abundant cytoplasm and increased formations of membrane protrusions suggesting these cells were activated (Antonios et al., 2013).

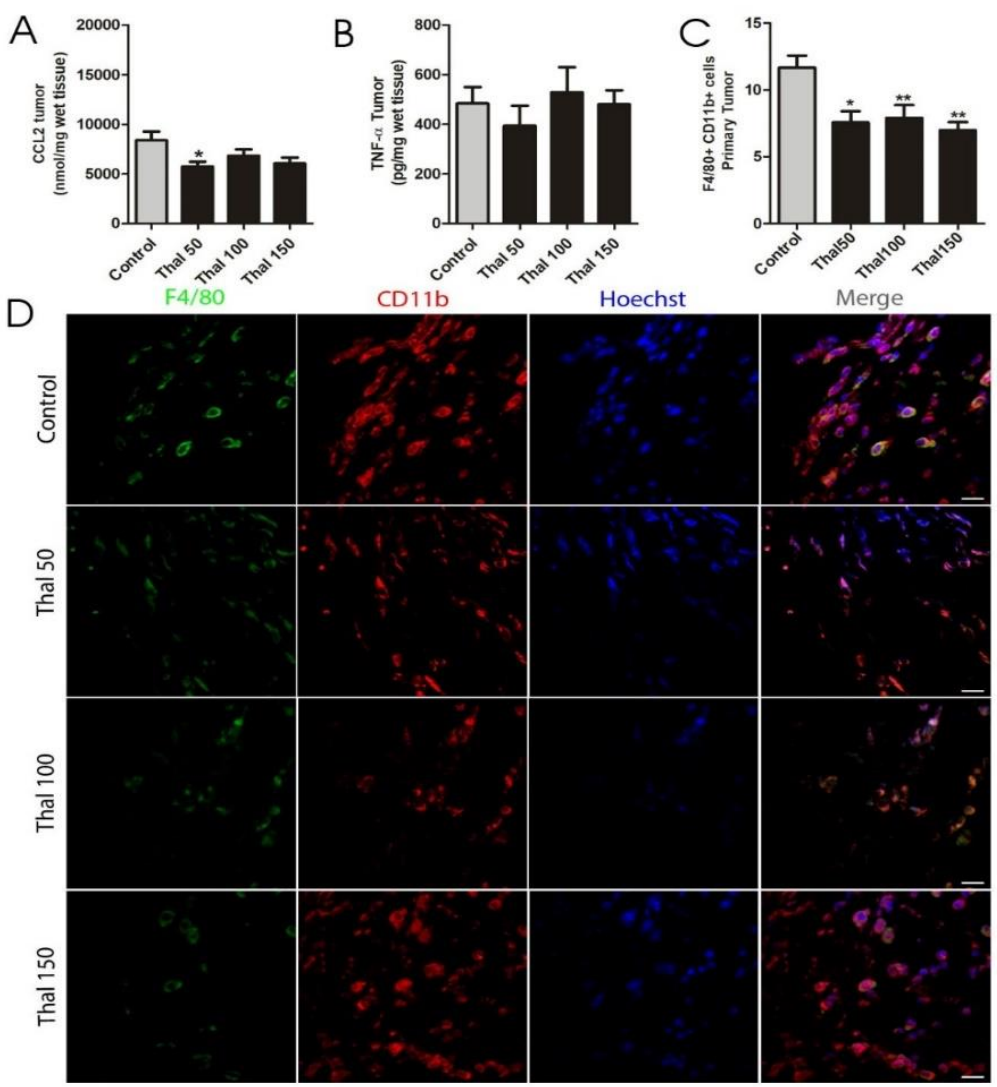

Figure 3. Effect of Thal administration on cytokines and TAMs on the primary tumor. (A-B) Effect of Thal administration at doses of 50,100 , and $150 \mathrm{mg} / \mathrm{kg}$ body weight or vehicle (control group) in CCL2 and TNF- $\alpha$ levels, respectively. (C) TAMs quantification (D) Representative confocal images. Bars represent $20 \mu \mathrm{M}$. Results are shown as the mean \pm SEM. One-way ANOVA test followed by the Student-Newman-Keuls post-hoc test to evaluate differences in A, B and D. $* P<0.05$, $* * P<0.01$, and $* * * P<0.001$. 

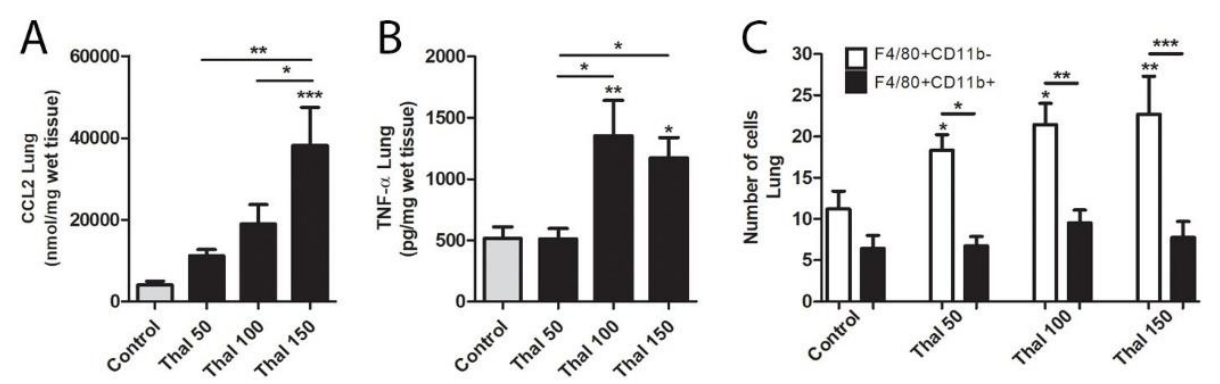

D

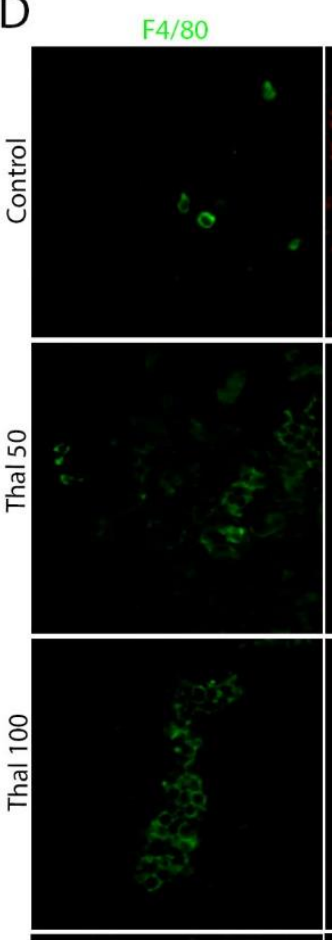

CD11b

Hoechst

Merge
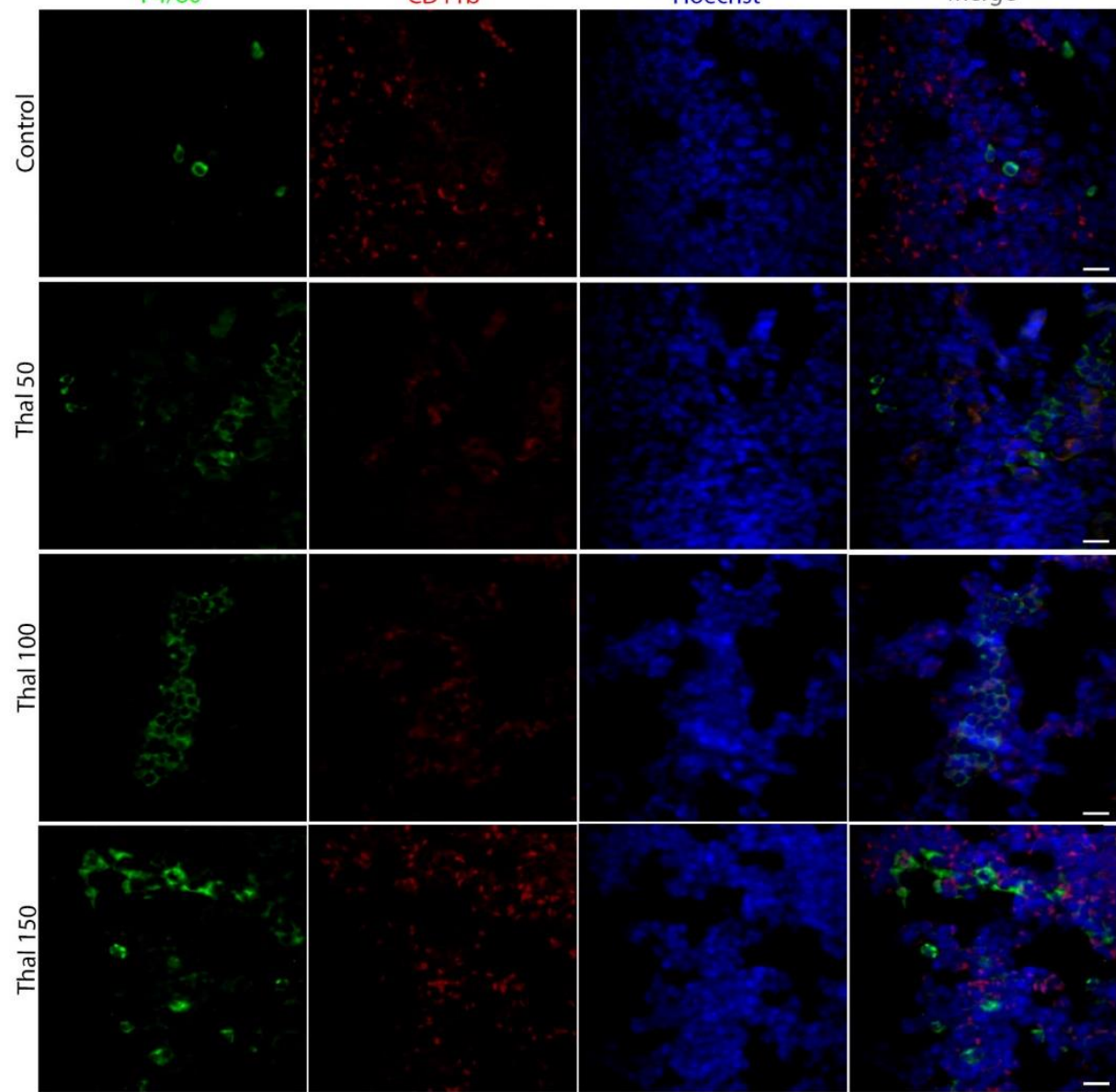

Figure 4. Effect of Thal administration on cytokines and TAMs on the lung. (A-B) Effect of Thal administration at doses of 50,100, and $150 \mathrm{mg} / \mathrm{kg}$ body weight or vehicle (control group) in CCL2 and TNF- $\alpha$ levels, respectively. (C) Representative confocal images. Bars represent $20 \mu \mathrm{M}$. (D) TAMs quantification. Results are shown as the mean \pm SEM. One-way ANOVA test followed by the Student-Newman-Keuls post-hoc test to evaluate differences in A, B and D. $* P<0.05$, $* * P<0.01$, and $* * * P<0.001$.

Next, we performed an iNOS single staining, a murine M1 polarization marker (Torroella-Kouri et al., 2005; Laoui et al., 2011; Antonios et al., 2013). The iNOS expression was found in the cytoplasm of endothelial cells and leukocytes infiltrated in the primary tumor (Fig. 5A). In the lung, the iNOS expression was more restricted to inflammatory cells present in blood vessels and their vicinity (Fig. 5C). In contrast, the lung parenchyma presented a weak to none iNOS expression. However, inflammatory cells infiltrated in the metastatic nodules showed a positive iNOS expression. The quantification 
analyses revealed higher iNOS expression in tumors treated with 100 and $150 \mathrm{mg} / \mathrm{kg}$ of Thal as compared to the control group $(P<0.001)$ (Fig. 5B). In contrast, in the lung, the iNOS expression showed higher in

Tumor
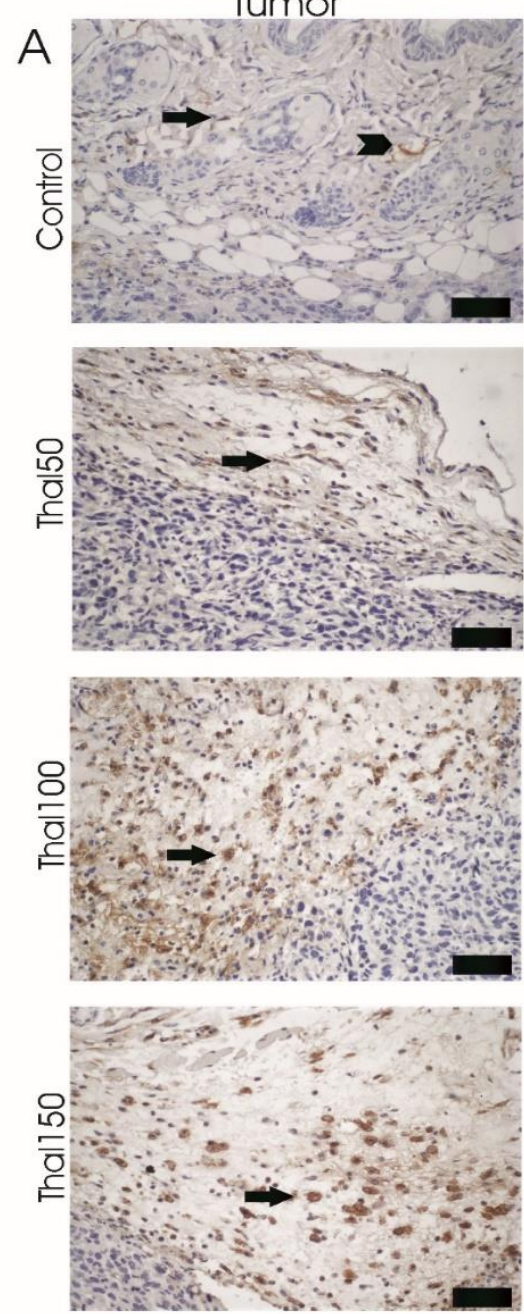

B

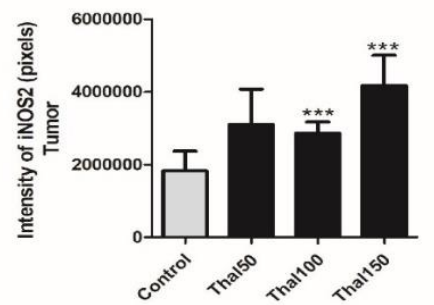

all treated groups as compared to the control group. $(P<0.001)$ (Fig. 5D)
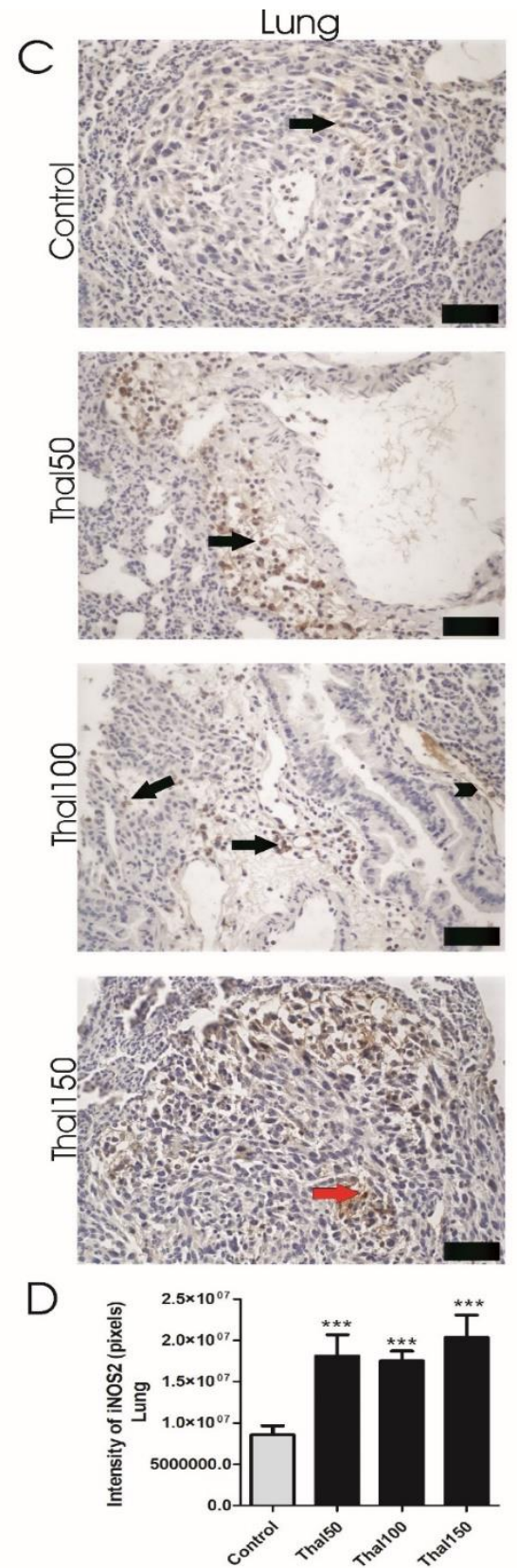

Figure 5. Thalidomide treatment increases tissue expression of inducible nitric oxide synthase enzyme (iNOS) in primary tumors and lungs from 4T1 tumor-bearing mice. (A) Representative images of tumor cross-sections stained with 3,3'-diaminobenzidine (DAB) by immunohistochemistry. Arrows show stained inflammatory cells presented in peripheral areas of primary tumors. Arrowhead indicates the iNOS expression in blood vessels. (B) iNOS quantification. (C) Representative images of lung cross-sections stained with DAB by immunohistochemistry. Arrows show stained inflammatory cells presented in the vicinity of blood vessels and lung parenchyma. Red arrowhead shows stained inflammatory cells infiltrated in the lung metastasis nodule. (D) iNOS quantification. Results are shown as the mean \pm SEM. One-way ANOVA test followed by the Student-Newman-Keuls post-hoc test to evaluate differences in A, B and D. * $P<0.05$ and $* * P<0.01$. 


\section{DISCUSSION}

Our previous reports have demonstrated that Thal used as a monotherapy therapy displays antitumor activity in murine (Souza et al., 2012, Reis et al., 2014) and canine mammary tumor models (Campos et al., 2017, 2018). In this work, we attempted to understand Thal's potential immunomodulatory effect on TAMs using a murine metastatic breast cancer model. Our findings demonstrated that Thal's prolonged administration exhibited an immunomodulatory and an anti-tumor action in the primary tumor and lung metastases of 4T1 tumor-bearing mice. While higher Thal doses induced inflammation in the primary tumor and metastatic lungs, marked differences were found in TAMs infiltration between these two sites. In the lung, higher doses of Thal have been associated with accumulation of F4/80+CD11b- macrophages, whereas in the primary tumor, these cells showed decreased abundance after Thal therapy.

Thalidomide therapy in human medicine has been associated with certain side effects, including peripheral neuropathy, thrombotic events, constipation, and drowsiness, particularly when used in high doses (Eleutherakis-Papaiakovou et al., 2004). In this study, the laboratory parameters did not show significant side effects after Thal administration. Thal reduced the tumor growth and neoplastic proliferation of the $4 \mathrm{~T} 1$ primary tumors and their lung metastasis at the higher dose. Considering the growth curve, Thal's efficacy at dose $150 \mathrm{mg} / \mathrm{kg}$ appeared to be higher at day 16 than the difference decreases until the end of treatment. However, these animals still presented a smaller number of metastatic lung nodules after Thal therapy. Our group also reported similar data in spontaneous canine mammary tumors, showing hindered lung metastasis progression after Thal therapy (Campos et al., 2017).

Thal has been used in cancer treatment, mostly due to its anti-angiogenic potential (Stewart, 2014). However, the Thal immunomodulatory effect has also been shown as an important tumor inhibition mechanism in mouse cancer models (Kawamata et al., 2006) and human cancer therapy (Stewart, 2014). In the current study, we have only focused on assessing tumor proliferation and TAMs infiltration in response to different doses of Thal. Histological analyses revealed that Thal's anti-tumor effect was accompanied by an increase in the inflammatory cells in the tumor microenvironment from the primary and secondary metastatic sites. Mononuclear cells appeared to be predominantly increased in the primary tumor after high doses of Thal. Additionally, confocal microscopy revealed that these mononuclear cells consisted of a low abundance of TAMs. These findings are corroborated by previous studies suggesting an immunomodulatory effect of Thal on different mononuclear immune cell populations (Kawamata et al., 2006), including M2 macrophages (Wang et al., 2020).

Metastasis is a major contributor to deaths from solid tumors (Gupta and Massagué, 2006). Breast cancer may metastasize to the lymph nodes and distant organs, the lung being one of the preferential sites for breast cancer metastases (Rahman and Mohammed, 2015). Our work shows that Thal reduced lung metastasis associated with increased macrophage infiltration, and it was observed more significantly in the higher dose of Thal (e.g., $150 \mathrm{mg} / \mathrm{kg}$ ). In the lungs, TAMs showed two phenotypes: F4/80 CD $11 b^{-}$ and $\mathrm{F} 4 / 80^{+} \mathrm{CD} 11 \mathrm{~b}^{+}$cells. The first phenotype described as F4/80+CD11 b- macrophages showed a progressive increase in the lung after Thal administration.

On the other hand, the $\mathrm{F} 4 / 80^{+} \mathrm{CD} 11 \mathrm{~b}^{+}$ macrophages population did not change after Thal therapy. Alveolar macrophages have been shown to express an $\mathrm{F} 4 / 80^{+} \mathrm{CD} 11 \mathrm{~b}^{-}$phenotype alongside other markers, while lung monocytes and interstitial macrophages express an $\mathrm{F} 4 / 80^{+} \mathrm{CD} 11 \mathrm{~b}^{+}$phenotype (Zaynagetdinov et al., 2013). In normal adult mice, alveolar macrophages account for the vast majority of cells obtained by bronchoalveolar lavage. These cells present oval nuclei and developed cytoplasm, different than interstitial macrophages that present a size similar to monocytes, oval nuclei, and less developed cytoplasm (Zaynagetdinov et al., 2013). After activation, alveolar macrophages display increased formations of membrane protrusions responsible for their phagocytosis activity (Boehme et al., 2015). These cells can present a classical activation (M1 macrophages) profile or an alternative activation (M2 macrophages) profile depending on the cytokine milieu. There were found high numbers of cells with oval nuclei in Thal-treated groups, abundant 
cytoplasm, and increased formations of membrane protrusions suggesting these cells were activated alveolar macrophages. The lung tissue of Thal-treated mice also presented with greater CCL2 and TNF- $\alpha$ levels, and iNOS expression. TAMs in contact with interferon- $\gamma$ (IFN- $\gamma$ ) and of other proinflammatory agents such as TNF- $\alpha$ and bacterial lipopolysaccharide (LPS) polarize to an M1-like phenotype. This classical activation results in improved anti-tumor capacity and enhanced secretion of proinflammatory cytokines, such as TNF- $\alpha$, interleukin-12 (IL-12) e oxide nitric (NO), to further strengthen the cellmediated adaptive immunity (Torroella-Kouri et al., 2005; Laoui et al., 2011; Murray et al., 2014).

In contrast, alternatively activated macrophages or M2-like macrophages are polarized by IL-4 and IL-13 and other stimuli such as glucocorticoid hormones and immune complexes (Laoui et al., 2011; Murray et al., 2014). Opposite to M1-like activation, these macrophages are associated with immunosuppressive and pro-tumoral capacities. A previous study has demonstrated that Thal can act by switching the M2 to M1 phenotype of murine macrophages in the asthma disease model (Lee et al., 2015). Moreover, Thal treatment also reduced M2 macrophages in primary tumors of 4T1 tumor-bearing mice (Wang et al., 2020). Taken together, our results show that Thal treatment induces the recruitment of TAMs on lungs, and it reduces them on primary tumors of 4T1 tumor-bearing mice. To better elicit which TAMs populations are present in these two sites, the phenotyping of TAMs by flow cytometer would consist of a great approach. However, how the Thal treatment used as a single agent presented modest inhibition on metastatic development of 4T1 tumor, we think future studies combining Thal and a chemotherapy drug could represent a better strategy.

\section{CONCLUSION}

In conclusion, our study demonstrated that Thal treatment enhanced the TAMs infiltration in lung metastases and decreased it in the primary tumor of 4T1 tumor-bearing mice. These effects were associated with a decrease in neoplastic proliferation and metastatic lung nodules.

\section{ACKNOWLEDGMENTS AND FUNDING}

This work was supported in part by the Brazilian National Council for Scientific and Technological Development and Coordination for the Improvement of Higher Education Personnel (CAPES). The microscopic data shown in this work were obtained using the microscopes of "Centro de Aquisição e Processamento de Imagens" (CAPI -ICB/UFMG).

\section{REFERENCES}

ANTONIOS, J.K.; YAO, Z.; LI, C. et al. Macrophage polarization in response to wear particles in vitro. Cell. Mol. Immunol., v.10, p.471-482, 2013.

BOEHME, J. D.; PIETKIEWICZ, S.; LAVRIK, I. et al. Morphological and Functional Alterations of Alveolar Macrophages in a Murine Model of Chronic Inflammatory Lung Disease. Lung, v.193, p.947-953, 2015.

CAMPOS, C.B.; LAVALLE, G.E.; LIGÓRIO, S.F. et al. Thalidomide treatment in a canine mammary gland carcinosarcoma presenting pulmonary metastasis. $A d v$. Anim. Vet. Sci., v.5, p.120-126, 2017.

CAMPOS, C.B.; LAVALLE, G.E.; MONTEIRO, L.N. et al. Adjuvant thalidomide and metronomic chemotherapy for the treatment of canine malignant mammary gland neoplasms. In Vivo, v.32, p.16591666, 2018.

DUPRÉ, S.A.; REDELMAN, D.; HUNTER, K.W. The mouse mammary carcinoma 4T1: Characterization of the cellular landscape of primary tumours and metastatic tumour foci. Int. J. Exp. Pathol., v.88, p.351360, 2007.

ELEUTHERAKIS-PAPAIAKOVOU, V.; BAMIAS, A.; DIMOPOULOS. M.A. Thalidomide in cancer medicine. Ann. Oncol., v.15, p.1151-1160, 2004.

ESTRELA-LIMA, M.S.; ARAUJO, J.M.; COSTANETO, A. et al. Immunophenotypic features of tumor infiltrating lymphocytes from mammary carcinomas in female dogs associated with prognostic factors and survival rates. BMC Cancer, v.10, p.1-14, 2010.

GUPTA, G.P.; MASSAGUÉ, J. Cancer metastasis: building a framework. Cell, v.127, p.679-695, 2006.

ITO, T.; ANDO, H.; SUZUKI, T. et al. T Identification of a primary target of thalidomide teratogenicity. Science, v.327, p.1345-1350, 2010.

KAWAMATA, D.; ITO, T.; ODANI, T. et al. Thalidomide suppresses melanoma growth by activating natural killer cells in mice. Oncol. Rep., v.16, p.1231-1236, 2006. 
LAOUI, D.; MOVAHEDI, K.; VAN OVERMEIRE, E. et al. Tumor-associated macrophages in breast cancer: distinct subets, distinct functions. Int. J. Dev. Biol., v.55, p.861-867, 2011 .

LEE, H.S.; KWON, H.S.; PARK, D.E. et al. Thalidomide inhibits alternative activation of macrophages in vivo and in vitro a potential mechanism of anti-asthmatic effect of thalidomide. PLoS One, v.10, p.1-15, 2015.

LINDSTEN, T.; HEDBRANT, A.; RAMBERG, A. et al. Effect of macrophages on breast cancer cell proliferation, and on expression of hormone receptors, uPAR and HER-2. Int. J. Oncol., v.51, p.104-114, 2017.

MCGARRY, M.P.; STEWART, C.C. Murine eosinophil granulocytes bind the murine macrophagemonocyte specific monoclonal antibody F4/80. $J$. Leukoc. Biol., v.50, p.471-478, 1991.

MEI, J.; XIAO, Z.; GUO, C. et al. Prognostic impact of tumor-associated macrophage infiltration in non-small cell lung cancer: a systemic review and meta-analysis. Oncotarget, v.7, p.34217-34228, 2016.

MILLRINE, D.; HARUHIKO, M.; TEI, M. et al. Immunomodulatory drugs inhibit TLR4 induced type-1 interferon production independently of Cereblon via suppression of the TRIF/IRF3 pathway. Int. Immunol., v.28, p.307-315, 2016.

MURRAY, P.J.; ALLEN, J.E.; BISWAS, S.K. et al. Macrophage activation and polarization: nomenclature and experimental guidelines. Immunity, v.41, p.14-20, 2014.

POLLARD, J.W. Macrophages define the invasive microenvironment in breast cancer. J. Leukoc. Biol., v.84, p.623-630, 2008

PULASKI, B.A.; OSTRAND-ROSENBERG, S Mouse 4T1 breast tumor model. Curr. Protoc. Immunol., v.20, unit.20.2, 2001.

QUAIL, D.; JOYCE J. Microenvironmental regulation of tumor progression and metastasis. Nat. Med., v.19, p.1423-1437, 2013.
RAHMAN, M.; MOHAMMED, S. Breast cancer metastasis and the lymphatic system. Oncol. Lett., v.10, p.1233-1239, 2015.

REIS, D. C.; SOUZA, C. M.; CAMPOS, L. C. et al. halidomide promotes leukocytosis in mice inoculated with 4T1 mammary carcinoma. J. Bras. Patol. Med. Lab., v.50, p;64-66, 2014.

REIS, D.C.; DAMASCENO, K.A.; CAMPOS, C.B. et al. Versican and tumor-associated macrophages promotes tumor progression and metastasis in canine and murine models of breast carcinoma. Front Oncol., v.9, p.1-14, 2019.

RUFFELL, B.; AU, A.; RUGO, H.S. et al. Leukocyte composition of human breast cancer. Proc. Natl. Acad. Sci., v.109, p.2796-2801, 2012.

SOUZA, C.M.; CARVALHO, L.F.; VIEIRA, T.S. et al. Thalidomide attenuates mammary cancer associatedinflammation, angiogenesis and tumor growth in mice. Biomed. Pharmacother., v.66, p.491-498, 2012.

STEWART, A.K. How thalidomide works against cancer. Science, v.343, p.256-257, 2014.

TORROELLA-KOURI, M.; MA, X.; PERRY, G. et al. Diminished expression of transcription factors nuclear Factor $\kappa \mathrm{B}$ and $\mathrm{CCAAT} /$ Enhancer Binding Protein Underlies a Novel Tumor Evasion Mechanism Affecting Macrophages of Mammary Tumor-Bearing Mice. Cancer Res., v.65, p.10578-10585, 2005.

WANG, X.; SHEN, Y.; MENGLV, L. et al. Thalidomide suppresses breast cancer tumor growth by inhibiting tumor-associated macrophage accumulation in breast tumor-bearing mice. Eur. J. Pharm. Sci., v.151, p.1-7, 2020.

ZAYNAGETDINOV, R.; SHERRILL, T.P.; KENDALL, P.L. et al. Identification of myeloid cell subsets in murine lungs using flow cytometry. Am. $J$. Resp. Cell Mol. Biol., v.49, p.180-189, 2013.

ZHU, Y.X.; BRAGGIO, E.; SHI, C.X. et al. Cereblon expression is required for the antimyeloma activity of lenalidomide and pomalidomide. Blood, v.118, p.47714779, 2011. 